\title{
Current Management of Atherosclerotic Renovascular Disease - What Have We Learned from ASTRAL?
}

\author{
Constantina Chrysochou Philip A. Kalra \\ Renal Department, Salford Royal Hospital, Salford, UK
}

\section{Key Words}

Atheromatous renovascular disease - ASTRAL •

Revascularization - Renal functional outcome $\cdot$ Renal artery

stenosis $\cdot$ Renal angioplasty $\cdot$ Hypertension

\begin{abstract}
With an increasingly ageing and atherosclerotic-prone population, clinical encounters with patients with atheromatous renovascular disease (ARVD) are commonplace. ARVD is frequently associated with chronic kidney disease (CKD) and hypertension, but evidence suggests that causality only occurs in the minority and it is likely that many atherosclerotic renal artery stenosis (RAS) lesions are incidental. Its association with extensive cardiovascular co-morbidity predisposes to a high patient mortality. The availability of renal angioplasty and stenting, which are generally safe techniques for dilating RAS lesions, has led to widespread use of these endovascular therapies in ARVD, but the outcomes after treatment have been inconsistent, with no clear evidence of benefit in many patients. There has been a great need for a large and appropriately powered randomised control trial to help guide clinical practice. In this review, we present an interpretation of the results of the recently reported Angioplasty and Stenting for Renal Artery Lesions (ASTRAL) trial as well as a brief review of the latest literature, so as to provide the latest guidance regarding the management of this common condition.

Copyright $\odot 2010$ S. Karger AG, Basel
\end{abstract}

\section{Background}

Although atheromatous renovascular disease (ARVD) is often a clinically silent disease, it may pose a considerable challenge for those involved in its investigation and management. It is usually part of a systemic syndrome that involves a complex interplay between intrinsic renal damage, concomitant cardiovascular disease and hypertension, so that patients are at high risk of and are prone to further renal and cardiovascular decline. Percutaneous interventional procedures that correct renal artery stenosis (RAS) lesions have been widely available for over 2 decades and whilst there is consensus regarding their benefit in specific clinical scenarios, there is less clarity regarding their applicability in the management of the majority of patients with ARVD, many of whom may have RAS as a co-incidental diagnosis.

\section{Epidemiology}

As many cases of ARVD are clinically unnoticed, its true epidemiology may be difficult to estimate. The incidence of ARVD in a large study of Medicare patients aged $>65$ years was 3.7 cases per 1,000 patient-years [1]. Disease prevalence is likely to be higher, and a survey that used Doppler ultrasound in an unselected sample of community-based elderly people revealed that almost $7 \%$ had

\section{KARGER}

Fax +4161306 1234 E-Mail karger@karger.ch www.karger.com
Prof. Philip A. Kalra

Department of Renal Medicine, Salford Royal Hospital

Stott Lane, Salford M6 8HD (UK)

Tel. +44161206 0509, Fax +441612065342

E-Mail philip.kalra@srft.nhs.uk 
anatomically significant RAS [2]. Diabetics and smokers are more at risk. ARVD is commonly associated with other vascular conditions, and so it is detected with a high frequency during investigation of other arterial beds; e.g. up to $30 \%$ of those with coronary artery disease [3], 30\% with congestive cardiac failure and almost $60 \%$ with peripheral vascular disease [4] can be shown to have some degree of ARVD.

The detrimental link between the heart and kidneys in ARVD is well described, and the presence of ARVD in patients with coronary disease independently doubles the risk of mortality even when coronary revascularization is performed [5]. In turn, the frequent presence of other comorbid cardiovascular diseases is reflected in the high incidence of premature cardiovascular events $[6,7]$ and death in patients with ARVD. Hence, only 5.1\% of ARVD patients have normal cardiac structure and function [8], and they are almost 6 times more likely to die than to reach dialysis [1]. Survival rates are linked to baseline renal function and blood pressure control [7], amongst other factors, with $>90 \%$ of patients being hypertensive. Whether ARVD is the cause of hypertension and CKD may often be difficult to elucidate, and it is likely that this atherogenic combination predates RAS development in many patients. Irrespective of whether a given RAS lesion is pathophysiologically important, supervening poorly controlled blood pressure in ARVD contributes to further renal decline and target organ damage. ARVD has been listed as the primary cause of end-stage renal disease (ESRD) in $5.8 \%$ of cases [9], and some investigators have found it to be responsible for at least $15 \%$ of ESRD in more elderly patients $[10,11]$. However, we suspect that most of these latter cases represent incidental complications of the hypertension and long-standing CKD; support for this view is available in a study of a US dialysis population in which twice as many patients (11\%) commenced dialysis with known ARVD than had this condition listed as the primary renal failure diagnosis [9].

\section{Renal Revascularization in ARVD}

Renal revascularization is performed in around $16 \%$ of newly diagnosed cases of ARVD in the United States [1], and endovascular procedures now account for over 95\% of all these interventions. Angioplasty with stent insertion, or primary stenting, is preferred to angioplasty alone due to better arterial patency and markedly lower restenosis rates in atherosclerotic ostial RAS [12, 13], but the use of drug-eluting [14] devices has not been found to provide any additional advantage [15]. There is general consensus, but no evidence base, that renal revascularization should be performed in patients with anatomically significant RAS who present with particular clinical scenarios such as life-threatening, sudden onset or 'flash' pulmonary oedema [16], or oligo-anuric acute kidney injury (AKI) [17]. Other clinicians would feel that ARVD patients with multidrug-resistant renovascular hypertension and those with steadily deteriorating renal function should undergo revascularization procedures. However, there is little evidence to support the use of revascularization in these latter situations, which is also true for the vast majority of ARVD patients who present with asymptomatic CKD or hypertension and severe RAS. Some studies have shown that revascularization is efficacious in improving hypertension control in $50-85 \%$ of patients [18], but these experiences are not replicated in the literature, and results in terms of renal functional outcome have been even more variable. Most of these studies have been retrospective [19], observational or non-randomised, and results have been conflicting $[20,21]$. Review of the many retrospective and prospective case series reported in the literature indicates that approximately $25 \%$ of patients show renal functional improvement, $25 \%$ deteriorate and $50 \%$ remain unchanged $[12,22]$ following revascularization. Distal athero-embolism may be partly responsible for some of the patients who deteriorate. In a prospective study of renal revascularization with distal embolic protection in a high-risk patient population, $60 \%$ of the filter baskets contained embolic material [15]. A minority of investigators have demonstrated that the use of distal protection embolic devices benefits renal functional outcome [23], but these findings have not been translated into a widespread change in practice by the renal stenting community.

Also, it should not be overlooked that even in skilled hands renal endovascular intervention is not risk-free, with about $3 \%$ of patients suffering a major vascular complication and over 10\% having less serious (and usually reversible) adverse events such as contrast-related acute renal injury or major groin haematoma [24]. These risks may be increased in the elderly or those having many other co-morbidities. Angiotensin-converting enzyme inhibitors (ACE-I) and angiotensin receptor blockers (ARB) have specific renoprotective effects, and guidelines endorse these drugs as first choice for the treatment of hypertension in renal disease [25], particularly with CKD and proteinuria $>1 \mathrm{~g} /$ day. However, in patients with severe bilateral RAS, or severe stenosis of the artery supplying a single functioning kidney, ACE-I/ARB can re- 
Table 1. RCTs comparing medical management to angioplasty \pm stent insertion in ARVD

\begin{tabular}{|c|c|c|c|c|c|}
\hline Trial & $\begin{array}{l}\text { Year of } \\
\text { publica- } \\
\text { tion }\end{array}$ & $\begin{array}{l}\mathrm{Pa}- \\
\text { tients } \\
\mathrm{n}\end{array}$ & $\begin{array}{l}\text { Randomised } \\
\text { treatment }\end{array}$ & Main endpoints & Findings \\
\hline $\begin{array}{l}\text { Webster } \\
\text { et al. [29] }\end{array}$ & 1998 & 55 & $\begin{array}{l}\text { Angioplasty vs. } \\
\text { medical treatment }\end{array}$ & $\begin{array}{l}\text { Primary: } \mathrm{BP} \text { and } \mathrm{sCr} \text { at } 6 \text { months } \\
\text { and the change in these from } \\
\text { baseline; secondary: major events }\end{array}$ & $\begin{array}{l}\text { Patients with bilateral RAS randomised to angioplasty } \\
\text { experienced a statistically significant fall in BP; } \\
\text { no clinical or biochemical difference in outcome } \\
\text { noted in either group overall }\end{array}$ \\
\hline $\begin{array}{l}\text { Plouin } \\
\text { et al. [30] }\end{array}$ & 1998 & 49 & $\begin{array}{l}\text { Angioplasty } \\
( \pm \text { stent insertion }) \\
\text { vs. medical treatment }\end{array}$ & $\begin{array}{l}\text { Primary: } \mathrm{BP} \text { at termination and the } \\
\text { change from baseline; secondary: } \\
\text { treatment score and the incidence } \\
\text { of complications }\end{array}$ & $\begin{array}{l}\text { Mean BP did not differ between either group at } \\
6 \text { months; angioplasty resulted in more complica- } \\
\text { tions, but was more drug-sparing }\end{array}$ \\
\hline $\begin{array}{l}\text { van Jaarsveld } \\
\text { et al. [28] }\end{array}$ & 2000 & 106 & $\begin{array}{l}\text { Angioplasty vs. } \\
\text { medical treatment }\end{array}$ & $\begin{array}{l}\text { Primary: } \mathrm{BP} \text { at } 3 \text { and } 12 \text { months; } \\
\text { secondary: treatment score, sCr, } \\
\text { sCr clearance, patency, incidence } \\
\text { of complications }\end{array}$ & $\begin{array}{l}\text { Mild drug-sparing effect noted at } 3 \text { months in angio- } \\
\text { plasty group; no significant differences in } \mathrm{BP}, \mathrm{sCr} \text { or } \\
\text { drug dose between each group at } 1 \text { year; } 22 \text { patients } \\
\text { in medical arm crossed over to angioplasty on clinical } \\
\text { grounds }\end{array}$ \\
\hline $\begin{array}{l}\text { van de Ven } \\
\text { et al. [31] }\end{array}$ & 1999 & 84 & $\begin{array}{l}\text { Angioplasty vs. } \\
\text { angioplasty }+ \text { stent } \\
\text { insertion }\end{array}$ & $\begin{array}{l}\text { Primary: primary success rate of } \\
\text { procedure, patency rate at } 6 \text { months; } \\
\text { secondary: sCr and BP outcomes }\end{array}$ & $\begin{array}{l}\text { Primary success rate was } 57 \% \text { (angioplasty alone) vs. } \\
88 \% \text { (angioplasty + stent), with better patency rate at } \\
6 \text { months ( } 29 \text { vs. } 75 \% \text { ) and lower restenosis rates ( } 48 \\
\text { vs. } 14 \% \text { ) for the angioplasty + stent group; no differ- } \\
\text { ence in intention to treat for clinical results in either } \\
\text { group }\end{array}$ \\
\hline $\begin{array}{l}\text { Bax } \\
\text { et al. [32] }\end{array}$ & 2009 & 140 & $\begin{array}{l}\text { Angioplasty }+ \text { stent } \\
\text { vs. medical treatment }\end{array}$ & $\begin{array}{l}\text { Primary: reduction in eGFR }>20 \% \\
\text { compared to baseline; secondary: } \\
\text { changes in BP, safety and cardio- } \\
\text { vascular morbidity and mortality }\end{array}$ & $\begin{array}{l}22 \% \text { of patients in the medication group and } 16 \% \\
\text { in the stent group reached the primary endpoint; } \\
\text { no significant difference in terms of primary or sec- } \\
\text { ondary outcomes between either group; a number } \\
\text { of stent-related complications occurred, including } \\
2 \text { stent-related deaths }\end{array}$ \\
\hline
\end{tabular}

$\mathrm{BP}=$ Blood pressure; $\mathrm{sCr}=$ serum creatinine.

duce or eliminate glomerular filtration and may cause severe and progressive renal failure [26]. The risk is higher in bilateral RAS.

The ONTARGET study [27] has also raised questions regarding the clinical safety of combination therapy with ACE-I/ARB. In high-cardiovascular-risk patients aged $>55$ years, the hazards of the combination were found to be in excess of any benefits observed, when compared to therapy with sole agents.

\section{Rationale for a Large Randomised Controlled Trial}

To date, there have been 5 published randomised clinical trials (RCTs) comparing percutaneous renal revascularization and medical management in a mix of ARVD patients with hypertension and renal function varying from normal to moderate CKD (table 1) [28-32]. All 5 studies had small patient numbers (the largest study, the STent Placement and Blood Pressure and Lipid-Lowering for the Prevention of Progression of Renal Dysfunction Caused by Atherosclerotic Ostial Stenosis of the Renal Artery trial, acronym 'STAR', enrolled 140 patients [32]) and only a short follow-up period. One of these RCTs primarily investigated the effectiveness of stenting over angioplasty in patients with ostial RAS, and has been alluded to already [31]. In the 3 other earlier studies [2830], the revascularization technique did not involve stent insertion but angioplasty only; their major weaknesses were that none of them were powered adequately to address any of the main cardiovascular and renal functional outcomes relevant to patients with ARVD. A later meta-analysis of these 3 trials $(n=210)$ indicated that the mean improvement in blood pressure was slightly better in patients undergoing angioplasty [33]. The results of the fifth RCT, the STAR trial [32], were published in 2009. It too was underpowered in relation to its primary endpoint, which was the reduction in the number of patients suffering a $>20 \%$ decrease in estimated glomerular filtration rate (eGFR) at follow-up after renal artery stenting 
(predicted to occur in $50 \%$ of patients over 2 years in the medical therapy arm, falling to $20 \%$ of revascularized patients). In fact, only $22 \%$ of the patients in the medical therapy arm reached this endpoint, and only 46 of 64 patients allocated to revascularization actually underwent the procedure; not surprisingly, there was no difference in renal functional change or in any of the secondary endpoints (blood pressure control, cardiovascular safety events and mortality) between the 2 arms of the study. Furthermore, almost $10 \%$ of the patients who underwent revascularization either died or developed ESRD as a direct or indirect result of the procedure.

In order to fill this evidence gap in the management of atherosclerotic RAS the Angioplasty and Stenting for Renal Artery Lesions (ASTRAL) trial [34] was designed in the UK, and commenced patient recruitment in September 2000. The trial compared 2 equal-sized groups of patients with significant anatomical atherosclerotic RAS who were randomised to either endovascular revascularization with standard medical therapy (usually statin, anti-platelet and anti-hypertensive therapy), or to standard medical therapy alone. The primary endpoint was the rate of change of renal function over time, with secondary endpoints of blood pressure control, cardiovascular and renal events and mortality. After a recruitment period of 7 years, 806 patients were randomised, making ASTRAL almost 8 times larger than the largest of the previous RCTs. In all, 57 centres entered patients into ASTRAL, 53 of these were from the UK and 4 from Australasia. The initial results of ASTRAL have now been released, and the major findings are summarised below.

\section{ASTRAL: Patient Population}

A total of 806 patients (403 in each randomisation arm) were enrolled into the ASTRAL trial. The initial results were reported after all surviving patients had completed a minimum of 12 months follow-up, and so they encompass a mean follow-up period of 33.6 months. Baseline demographics were almost identical in the 2 groups, the notable characteristics (approximate means with ranges where appropriate) being age $70(42-88)$ years, 63\% males, creatinine 179 (64-750) $\mu \mathrm{mol} / \mathrm{l}$, eGFR $40(5-125) \mathrm{ml} / \mathrm{min}, 74 \%$ current or ex-smokers, $30 \%$ diabetics, $49 \%$ previous ischaemic heart disease, $41 \%$ peripheral vascular disease, $19 \%$ stroke and cholesterol 4.7 $\mathrm{mmol} / \mathrm{l}$. The average degree of stenosis for the most severe RAS lesion in each patient was 76\% (three-fifths of patients had RAS $>70 \%$ ) and renal length was $9.8 \mathrm{~cm}$.
Mean blood pressures were 149/76 and 152/76 mm Hg in the revascularized and medically-managed patients, respectively, and patients were receiving an average of 2.8 different classes of anti-hypertensive medication.

\section{ASTRAL: Key Findings}

\section{Renal Function}

As shown in the plot of serum creatinine (fig. 1) there was a minor deterioration in renal function over time in both treatment arms, but no difference in this change between the arms. The difference in reciprocal creatinine plot over time was the stated primary endpoint for the trial, but this too showed no significant difference between the 2 arms.

\section{Blood Pressure}

There was a progressive and very similar fall in blood pressure in both treatment arms (fig. $2 \mathrm{a}$ and $\mathrm{b}$ ) throughout the follow-up. This amounted to about $8 \mathrm{~mm} \mathrm{Hg}$ in systolic and $4 \mathrm{~mm} \mathrm{Hg}$ in diastolic pressure at 36 months follow-up.

\section{Renal Events}

Significant renal events were analysed by the composite endpoint of time to any one of ARF, start of dialysis for ESRD, renal transplantation, nephrectomy or death due to ESRD. To date, $22 \%$ of patients in each treatment arm have had a renal event ( $\mathrm{p}=0.97)$; the rate of progression to dialysis-requiring ESRD has been approximately $2 \%$ per year in each treatment arm (36 patients who had been randomised to revascularization and 40 to medical therapy).

\section{Vascular Events}

Significant vascular endpoints included myocardial infarction, stroke, vascular death, hospitalization for angina or cardiac failure, coronary artery or peripheral vascular procedures. These have occurred in about $50 \%$ of all patients, with no difference between the treatment $\operatorname{arms}(\mathrm{p}=0.96)$.

\section{Mortality}

This has been almost identical in the 2 arms (103 patients in the revascularization arm and 106 in those allocated to medical therapy); as shown in the Kaplan-Meier plot in figure 3 , the mortality rate has been approximately $8 \%$ per year. 


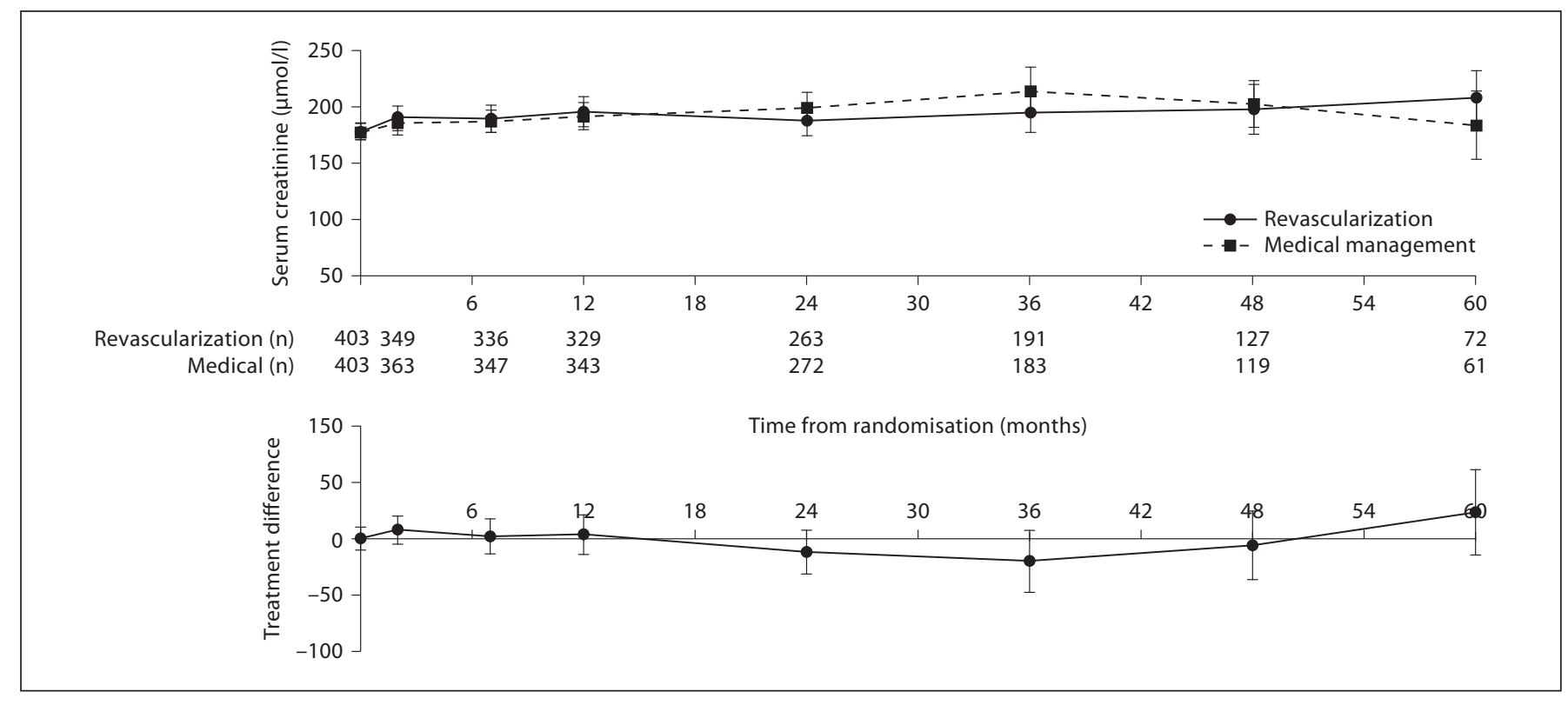

Fig. 1. Serum creatinine ( $\mu \mathrm{mol} / \mathrm{l})$ over time [adapted from 34, with permission from the New England Journal of Medicine].

\section{Complications of Revascularization}

As a result of the procedure, $6.8 \%$ of revascularized patients suffered significant complications; these included renal arterial perforation, thrombosis and embolisation ( 3 patients for each), serious AKI (5 patients) and groin haematoma/haemorrhage necessitating admission $(n=3)$. Another $20 \%$ of patients experienced less serious complications (mainly groin haematoma and short-lived renal dysfunction).

\section{Implications of the Initial ASTRAL Trial Results}

The ASTRAL trial has shown that in a large group of patients with significant anatomical atherosclerotic RAS, endovascular revascularization in addition to standard medical therapy does not improve renal functional outcome and blood pressure control, and does not reduce renal or cardiovascular events or mortality, when compared to treatment with medical therapy alone. These findings also have to be considered in the light of a significant number of revascularized patients suffering a serious complication from the procedure, which was also emphasised in the STAR study.

These findings coupled with other current evidence help guide the approach to managing patients with ARVD:

(1) In patients with clinically asymptomatic ARVD (e.g. those who are found to have the condition when re- ferred with stable CKD and/or moderate to severe hypertension), there is no worthwhile clinical benefit associated with renal revascularization.

(2) Our current medical therapy regime for these highrisk atherosclerotic patients appears to be quite effective. In ASTRAL, the annual mortality was around $8 \%$ for all patients; in the US Medicare study involving patients aged $>67$ years followed from 2000-2001, the annual mortality was $16.3 \%$ for patients with ARVD and $6.4 \%$ for those without the condition. About $85 \%$ of ASTRAL patients were receiving a statin at 1 year follow-up, and $80 \%$ were receiving anti-platelet therapy.

(3) An argument can be made to stop screening patients for suspected ARVD when they are being assessed for asymptomatic CKD and/or hypertension, as revascularization would not be recommended in these patients. However, it would be important that optimal medical therapy is administered in this situation - if the patients have evidence of extra-renal atherosclerotic disease, including asymptomatic arterial bruits, then they should receive this treatment. This recommendation also applies to the practice of 'drive-by angiography' which often culminates in 'drive-by stenting' typically during coronary angiographic investigative sessions [35]. Although no firm evidence exists, it is likely that many incidental and non-functional RAS lesions are being detected and inappropriately revascularized in this way. 


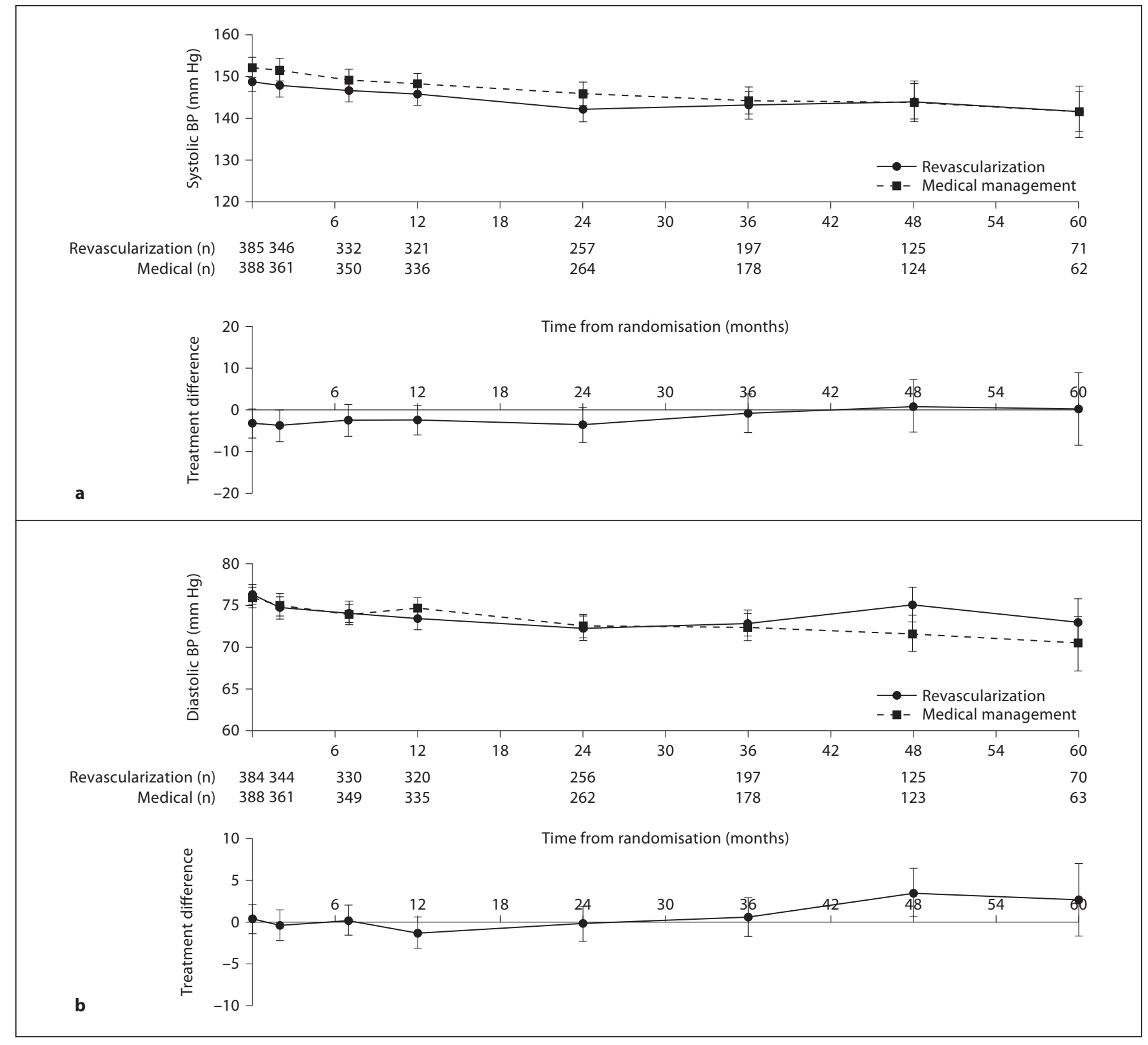

Fig. 2. a Systolic blood pressure (mm Hg) over time. b Diastolic blood pressure (mm Hg) over time [adapted from 34, with permission from the New England Journal of Medicine].

Current Indications for Revascularization in ARVD

Should patients with atherosclerotic RAS ever be subjected to revascularization therapy? ASTRAL never was going to be able to answer all of the questions regarding the value of revascularization in patients presenting with the following 5 specific clinical scenarios:

(1) Dialysis-requiring AKI: no trial data is available; anecdotal reports [14] show that patients can have major recovery of renal function with endovascular intervention, and there would appear to be more benefits than risks associated with revascularization.

(2) Flash pulmonary oedema: the same applies for patients presenting with severe RAS and sudden-onset pulmonary oedema that is not due to coronary artery disease; most clinicians would still recommend revascularization. 


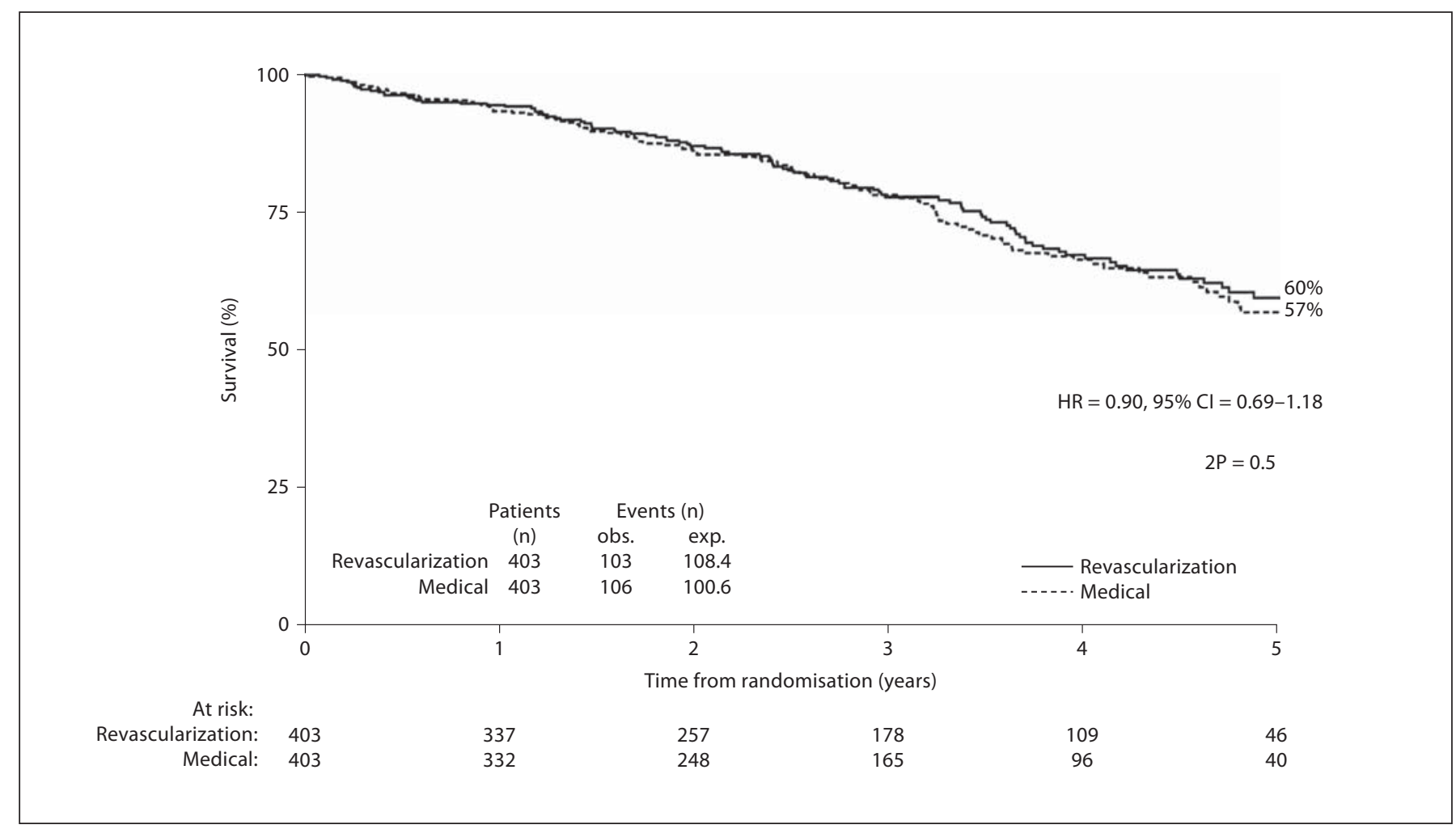

Fig. 3. Overall survival. $\mathrm{HR}=$ Hazard ratio; $\mathrm{CI}=$ confidence interval; obs. = observed; exp. = expected [adapted from 34 , with permission from the New England Journal of Medicine].

(3) Rapidly deteriorating renal function: this was examined in a pre-specified subgroup analysis within ASTRAL, but patient numbers were $<50$ in each group and although serum creatinine fell at 1 year in the revascularized patients, confidence intervals were wide and the result was non-significant. The CORAL trial [36], a study of 1080 ARVD patients again with 1:1 randomisation to revascularization:medical therapy, but with anatomical RAS more stringently assessed by an angiographic core laboratory, may be able to address this issue, otherwise, a future meta-analysis of such patients within ASTRAL, CORAL and STAR may be more informative.

(4) Very severe and resistant hypertension: no trial data exists. Post hoc analysis of ASTRAL data, and results from CORAL, may eventually shed light on the benefits of revascularization. Until then, some clinicians will feel obliged to attempt revascularization when patients have accelerated hypertension with severe RAS, or multidrugresistant hypertension (e.g. $>5$ medications).

(5) Patients with significant anatomical RAS whose renal function deteriorates with the use of agents blocking the renin-angiotensin system: again no trial data is avail- able to suggest that such patients have improved survival if revascularization is performed to facilitate improved 'renal tolerance' of these agents.

\section{Conclusion}

Optimal management of patients with ARVD requires an understanding of the disease processes at work. The degree of RAS is often not indicative of disease severity or severity of renal dysfunction [37], and early intra-renal damage by atherosclerosis, cholesterol formation, hypertension and cytokine release probably occur before the RAS is regarded as significant enough to warrant treatment. For example, experimentally induced hypercholesterolemia, a marker and risk factor for atherosclerosis, induces intra-renal inflammation, glomerulosclerosis, renal oxidative stress and fibrosis even in the absence of overt atherosclerotic plaques [38]. Similarly, hypertension, independently of RAS, has been shown to strongly correlate with a risk for renal atrophy in ARVD [39]. Thus, the cornerstone of ARVD management should in- 
clude lifestyle modification (e.g. smoking cessation) and optimum medical care that includes cardiovascular disease management and blood pressure reduction.

Although ASTRAL has significantly increased the evidence base regarding the management of patients with ARVD, many questions still remain including the value of revascularization in the specific clinical scenarios previ- ously described. Additional information will be provided in the future with analysis of longer term follow-up of the ASTRAL patients, and also when the results of the CORAL study (approximately 2011) are available. Whether renal revascularization can improve cardiac function and structure in patients with ARVD is also being investigated in 2 cardiac substudies of ASTRAL [40].

\section{References}

$\checkmark 1$ Kalra PA, Guo H, Kausz AT, Gilbertson DT, Liu J, Chen SC, Ishani A, Collins AJ, Foley $\mathrm{RN}$ : Atherosclerotic renovascular disease in United States patients aged 67 years or older: risk factors, revascularization, and prognosis. Kidney Int 2005;68:293-301.

$\checkmark 2$ Hansen KJ, Edwards MS, Craven TE, Cherr GS, Jackson SA, Appel RG, Burke GL, Dean $\mathrm{RH}$ : Prevalence of renovascular disease in the elderly: a population-based study. J Vasc Surg 2002;36:443-451.

3 Harding MB, Smith LR, Himmelstein SI, Harrison K, Phillips HR, Schwab SJ, Hermiller JB, Davidson CJ, Bashore TM: Renal artery stenosis: prevalence and associated risk factors in patients undergoing routine cardiac catheterization. J Am Soc Nephrol 1992;2:1608-1616.

4 Olin JW, Melia M, Young JR, Graor RA, Risius B: Prevalence of atherosclerotic renal artery stenosis in patients with atherosclerosis elsewhere. Am J Med 1990;88:46N-51N.

$\checkmark 5$ Conlon PJ, Little MA, Pieper K, Mark DB: Severity of renal vascular disease predicts mortality in patients undergoing coronary angiography. Kidney Int 2001;60:1490-1497.

6 Edwards MS, Craven TE, Burke GL, Dean RH, Hansen KJ: Renovascular disease and the risk of adverse coronary events in the elderly: a prospective, population-based study. Arch Intern Med 2005;165:207-213.

$\checkmark 7$ Wright JR, Shurrab AE, Cheung C, Waldek S, O’Donoghue DJ, Foley RN, Mamtora H, Kalra PA: A prospective study of the determinants of renal functional outcome and mortality in atherosclerotic renovascular disease. Am J Kidney Dis 2002;39:1153-1161.

$>8$ Wright JR, Shurrab AE, Cooper A, Kalra PR, Foley RN, Kalra PA: Left ventricular morphology and function in patients with atherosclerotic renovascular disease. J Am Soc Nephrol 2005;16:2746-2753.

>9 Guo H, Kalra PA, Gilbertson DT, Liu J, Chen SC, Collins AJ, Foley RN: Atherosclerotic renovascular disease in older US patients starting dialysis, 1996 to 2001. Circulation 2007; 115:50-58.

10 van Ampting JM, Penne EL, Beek FJ, Koomans HA, Boer WH, Beutler JJ: Prevalence of atherosclerotic renal artery stenosis in patients starting dialysis. Nephrol Dial Transplant 2003;18:1147-1151.
11 Mailloux LU, Napolitano B, Bellucci AG, Vernace M, Wilkes BM, Mossey RT: Renal vascular disease causing end-stage renal disease, incidence, clinical correlates, and outcomes: a 20-year clinical experience. Am J Kidney Dis 1994;24:622-629.

12 Harden PN, MacLeod MJ, Rodger RS, Baxter GM, Connell JM, Dominiczak AF, Junor BJ, Briggs JD, Moss JG: Effect of renal-artery stenting on progression of renovascular renal failure. Lancet 1997;349:1133-1136.

13 Zeller T, Frank U, Muller C, Burgelin K, Sinn L, Bestehorn HP, Cook-Bruns N, Neumann FJ: Predictors of improved renal function after percutaneous stent-supported angioplasty of severe atherosclerotic ostial renal artery stenosis. Circulation 2003;108:2244-2249.

14 Granillo GA, van Dijk LC, McFadden EP Serruys PW: Percutaneous radial intervention for complex bilateral renal artery stenosis using paclitaxel eluting stents. Catheter Cardiovasc Interv 2005;64:23-27.

15 Holden A, Hill A: Renal angioplasty and stenting with distal protection of the main renal artery in ischemic nephropathy: early experience. J Vasc Surg 2003;38:962-968.

16 Messina LM, Zelenock GB, Yao KA, Stanley JC: Renal revascularization for recurrent pulmonary edema in patients with poorly controlled hypertension and renal insufficiency: a distinct subgroup of patients with arteriosclerotic renal artery occlusive disease. J Vasc Surg 1992;15:73-80.

17 Chrysochou C, Sinha S, Chalmers N, Kalra PR, Kalra PA: Anuric acute renal failure and pulmonary oedema: a case for urgent action. Int J Cardiol 2009;132:e31-e33.

18 Steinbach F, Novick AC, Campbell S, Dykstra D: Long-term survival after surgical revascularization for atherosclerotic renal artery disease. J Urol 1997;158:38-41.

19 Bonelli FS, McKusick MA, Textor SC, Kos PB, Stanson AW, Johnson CM, Sheedy PF, Welch TJ, Schirger A: Renal artery angioplasty: technical results and clinical outcome in 320 patients. Mayo Clin Proc 1995; 70:1041-1052.

20 Kashyap VS, Sepulveda RN, Bena JF, Nally JV, Poggio ED, Greenberg RK, Yadav JS, Ouriel K: The management of renal artery atherosclerosis for renal salvage: does stenting help? J Vasc Surg 2007;45:101-108.
21 Textor SC: Revascularization in atherosclerotic renal artery disease. Kidney Int 1998; 53:799-811.

22 Ramos F, Kotliar C, Alvarez D, Baglivo H, Rafaelle P, Londero H, Sanchez R, Wilcox CS: Renal function and outcome of PTRA and stenting for atherosclerotic renal artery stenosis. Kidney Int 2003;63:276-282.

23 Henry M, Henry I, Polydorou A, Hugel M: Embolic protection for renal artery stenting. J Cardiovasc Surg (Torino) 2008;49:571589.

24 Leertouwer TC, Gussenhoven EJ, Bosch JL, van Jaarsveld BC, van Dijk LC, Deinum J, Man in 't Veld AJ: Stent placement for renal arterial stenosis: where do we stand? A metaanalysis. Radiology 2000;216:78-85.

25 Casas JP, Chua W, Loukogeorgakis S, Vallance P, Smeeth L, Hingorani AD, MacAllister RJ: Effect of inhibitors of the renin-angiotensin system and other antihypertensive drugs on renal outcomes: systematic review and meta-analysis. Lancet 2005;366:20262033

26 Schoolwerth AC, Sica DA, Ballermann BJ, Wilcox CS: Renal considerations in angiotensin converting enzyme inhibitor therapy: a statement for healthcare professionals from the Council on the Kidney in Cardiovascular Disease and the Council for High Blood Pressure Research of the American Heart Association. Circulation 2001;104:19851991.

27 Mann JF, Schmieder RE, McQueen M, Dyal L, Schumacher H, Pogue J, Wang X, Maggioni A, Budaj A, Chaithiraphan S, Dickstein K, Keltai M, Metsarinne K, Oto A, Parkhomenko A, Piegas LS, Svendsen TL, Teo KK, Yusuf S: Renal outcomes with telmisartan, ramipril, or both, in people at high vascular risk (the ONTARGET study): a multicentre, randomised, double-blind, controlled trial. Lancet 2008;372:547-553.

28 van Jaarsveld BC, Krijnen P, Pieterman H, Derkx FH, Deinum J, Postma CT, Dees A, Woittiez AJ, Bartelink AK, Man in 't Veld AJ, Schalekamp MA: The effect of balloon angioplasty on hypertension in atherosclerotic renal-artery stenosis. Dutch Renal Artery Stenosis Intervention Cooperative Study Group. N Engl J Med 2000;342:10071014. 
-29 Webster J, Marshall F, Abdalla M, Dominiczak A, Edwards R, Isles CG, Loose H, Main J, Padfield P, Russell IT, Walker B, Watson M, Wilkinson R: Randomised comparison of percutaneous angioplasty vs continued medical therapy for hypertensive patients with atheromatous renal artery stenosis. Scottish and Newcastle Renal Artery Stenosis Collaborative Group. J Hum Hypertens 1998;12:329-335.

>30 Plouin PF, Chatellier G, Darne B, Raynaud A: Blood pressure outcome of angioplasty in atherosclerotic renal artery stenosis: a randomized trial. Essai Multicentrique Medicaments vs Angioplastie (EMMA) Study Group. Hypertension 1998;31:823-829.

>31 van de Ven PJ, Kaatee R, Beutler JJ, Beek FJ, Woittiez AJ, Buskens E, Koomans HA, Mali WP: Arterial stenting and balloon angioplasty in ostial atherosclerotic renovascular disease: a randomised trial. Lancet 1999;353: 282-286.

>32 Bax L, Woittiez AJ, Kouwenberg HJ, Mali WP, Buskens E, Beek FJ, Braam B, Huysmans FT, Schultze Kool LJ, Rutten MJ, Doorenbos CJ, Aarts JC, Rabelink TJ, Plouin PF, Raynaud A, van Montfrans GA, Reekers JA, van den Meiracker AH, Pattynama PM, van de Ven PJ, Vroegindeweij D, Kroon AA, de
Haan MW, Postma CT, Beutler JJ: Stent placement in patients with atherosclerotic renal artery stenosis and impaired renal function: a randomized trial. Ann Intern Med 2009; 150:840-848.

-33 Ives NJ, Wheatley K, Stowe RL, Krijnen P, Plouin PF, van Jaarsveld BC, Gray R: Continuing uncertainty about the value of percutaneous revascularization in atherosclerotic renovascular disease: a meta-analysis of randomized trials. Nephrol Dial Transplant 2003;18:298-304.

34 ASTRAL Investigators, Wheatley K, Ives N, Gray R, Kalra PA, Moss JG, Baigent C, Carr S, Chalmers N, Eadington D, Hamilton G, Lipkin G, Nicholson A, Scoble J: Revascularization versus medical therapy for renal-artery stenosis. N Engl J Med 2009;361:1953-1962.

35 White CJ, Jaff MR, Haskal ZJ, Jones DJ, Olin JW, Rocha-Singh KJ, Rosenfield KA, Rundback JH, Linas SL: Indications for renal arteriography at the time of coronary arteriography: a science advisory from the American Heart Association Committee on Diagnostic and Interventional Cardiac Catheterization, Council on Clinical Cardiology, and the Councils on Cardiovascular Radiology and Intervention and on Kidney in Cardiovascular Disease. Circulation 2006;114:1892-1895.
36 Cooper CJ, Murphy TP, Matsumoto A, Steffes M, Cohen DJ, Jaff M, Kuntz R, Jamerson K, Reid D, Rosenfield K, Rundback J, D’Agostino R, Henrich W, Dworkin L: Stent revascularization for the prevention of cardiovascular and renal events among patients with renal artery stenosis and systolic hypertension: rationale and design of the CORAL trial. Am Heart J 2006;152:59-66.

-37 Suresh M, Laboi P, Mamtora H, Kalra PA: Relationship of renal dysfunction to proximal arterial disease severity in atherosclerotic renovascular disease. Nephrol Dial Transplant 2000;15:631-636.

>38 Chade AR, Rodriguez-Porcel M, Grande JP, Krier JD, Lerman A, Romero JC, Napoli C, Lerman LO: Distinct renal injury in early atherosclerosis and renovascular disease. Circulation 2002;106:1165-1171

-39 Zierler RE, Bergelin RO, Davidson RC, Cantwell-Gab K, Polissar NL, Strandness DE Jr: A prospective study of disease progression in patients with atherosclerotic renal artery stenosis. Am J Hypertens 1996;9: 1055-1061.

40 Hegarty J, Wright JR, Kalra PR, Kalra PA: The heart in renovascular disease - an association demanding further investigation. Int J Cardiol 2006;111:339-342.

\title{
Editorial Comment
}

\author{
M. El Nahas, Sheffield
}

Chrysochou and Kalra update the reader on the result of the ASTRAL trial of endovascular revascularization compared to medical therapy in ARVD. They conclude that revascularization with or without stenting is of little value in long-term blood pressure control or in affecting the course of CKD. This minireview is supported by the recent publication of the STAR study group from The Netherlands drawing a similar conclusion [1]. This is not too surprising, as ARVD is not a disease confined to the renal arteries as is the case in fibromuscular dysplasia; it is a disease of older age, invariably associated with extensive intra-renal vascular and glomerular ischemic pathology. Therefore, one would not expect that the stretching of stenosed renal arteries would improve blood flow through stenosed intra-renal arteries and arterioles or improve the perfusion of ischemically sclerosed glomeruli. The authors conclude that there remain some clinical situations when percutaneous transluminal angioplasty of renal arteries may be indicated. Many nephrologists will need to be convinced by some evidence before supporting some of these recommendations. In the mean- while, this editor would caution against investigators examining underpowered subgroups within trials as this is often misleading and can provide false-positive results. Nephrology is littered with negative clinical trials where investigators never fully accepted the evidence-based verdict; they continue to look for positive results in post hoc and underpowered subgroup analyses, but hopefully this will not occur with ASTRAL. After all, as ASTRAL clearly demonstrates, a negative result is as valuable to our practice as a positive one. The future of ARVD management will depend on developing better methods for estimating the role of large vessel occlusive disease regarding tissue oxygenation, injury and fibrosis [2].

\section{References}

Bax L, Woittiez AJ, Kouwenberg HJ, et al: Stent placement in patients with atherosclerotic renal artery stenosis and impaired renal function: a randomized trial. Ann Intern Med 2009;150:840-848.

- 2 Textor SC, Lerman L, McKusick M: The uncertain value of renal artery interventions: where are we now? JACC Cardiovasc Interv 2009;2:175182. 